\title{
Distribution of macroinvertebrates on intertidal rocky shores in Gorgona Island, Colombia (Tropical Eastern Pacific)
}

\author{
Edgardo Londoño-Cruz ${ }^{1 *}$, Luz Ángela López de Mesa-Agudelo ${ }^{1}$, Fatnori Arias-Galvez ${ }^{1}$, \\ David Leonardo Herrera-Paz ${ }^{1}$, Angélica Prado ${ }^{1}$, Luis Miguel Cuellar ${ }^{1}$ \& Jaime Cantera ${ }^{1}$ \\ 1. Ecomanglares Universidad del Valle, Calle 13 \# 100-00 Edi. 320 Laboratorio 4061, Cali-Colombia; edgardo.lon- \\ dono@correounivalle.edu.co, lopezdemesala@yahoo.com, arias_0114@hotmail.com, davidhepaz@gmail.com, ange- \\ likpraos@gmail.com, heeedejame3140@hotmail.com, jaime.cantera@correo univalle.edu.co
}

Recibido 18-X-2013. Corregido 20-XI-2013. Aceptado 19-XII-2013.

\begin{abstract}
Organisms found on rocky shores must endure harsh environmental conditions during tidal changes but scientific studies on tropical rocky shores are scarce, particularly in Colombian shores. Here we describe the spatial distribution of macroinvertebrates associated to the intertidal rocky ecosystems of Gorgona Island, Colombia (Tropical Eastern Pacific). Sampling was carried out in four localities around the Island: La Ventana and La Camaronera (sampled during October 2010) and La Mancora and El Muelle (sampled during March 2011). Two methodologies were used: rapid ecological assessments for qualitative data and quadrats for quantitative data. The richness, abundance, diversity (Shannon-Wiener H'), and evenness (Pielou J') of macroinvertebrates were determined for and compared between, using one way ANOVA, each locality and the three intertidal zones of La Ventana (see methods). One hundred twenty-one species of macroinvertebrates were found during the sampling period. In all localities, Mollusca was the richest and most abundant taxon (46\% of the species and $59 \%$ of the individuals), followed by Crustacea (32\% of the species and $33 \%$ of the individuals). The other groups accounted for the remaining $22 \%$ of the richness and $8 \%$ of the abundance. Several studies have demonstrated that mollusks and crustaceans are the richest and most abundant taxa in marine benthic communities. Most of the abundant species found were herbivores. The species composition varied among zones. The results of dominant species for each zone are consistent with the ones observed in other tropical rocky intertidal shores. All response variables showed a decreasing pattern from the low to the high intertidal (in La Ventana). Post-hoc results indicated that the high intertidal, the zone with the harshest environmental conditions, had significantly lower values than the other two zones for all response variables. Comparisons between the low intertidal zones of the different localities in Gorgona Island showed higher values in all response variables for localities with intertidal pools. The most topographically homogeneous localities showed the lowest richness, abundance, and diversity. Both, tide pools and substrate heterogeneity and/or micro-topography are known to offer refuge against extreme physical conditions to the intertidal dwelling organisms. Results suggest that environmental stress, heterogeneity, and stability are important factors affecting the spatial distribution of macroinvertebrate species on intertidal rocky shores of Gorgona Island. Rev. Biol. Trop. 62 (Suppl. 1): 189-198. Epub 2014 February 01.
\end{abstract}

Key words: marine macroinvertebrates, intertidal rocky ecosystem, Tropical Eastern Pacific, spatial distribution, Colombia.

Rocky shores are very common worldwide. These shores constitute the hard marine band of mineral (sedimentary, metamorphic, and magmatic rocks) or biological (e.g., coralline coasts) origin that faces the sea directly (Little \& Kitching, 1996). According to tide patterns, two zones can be distinguished: the subtidal (permanently underwater or submerged) and the intertidal (periodically covered by water) zones. Due to its easy access, the intertidal zone has been a very important ecosystem in the development of research studies and 
experiments on biology and ecology (Osman, 1977; Sousa, 1979a; 1979b; 1984; Shanks \& Wright, 1986; Davis \& Wilce, 1987).

Depending on the tidal ranges, three zones can be found in the intertidal: low zone (uncovered by the sea only during the lowest tides), middle zone (regularly flooded by the sea) and high zone (covered by the sea only during high tides); and depending on the slope, these shores can be divided into cliffs and rock beaches of different inclinations. Finally, depending on the substrate structure and composition different habitats can be found: cobbles, boulders, blocks, rock platform or better, a combination of these, and tide pools. In general terms, rocky shores are very heterogeneous, both in composition (the material of which they are made) and structure (morphological characteristics: slope, rugosity). Heterogeneity has been identified by several ecological studies as an important factor influencing the distribution and abundance of communities (Archambault \& Bourget, 1996). Heterogeneity of rocky shores gives special characteristics to the ecosystem which allows it to shelter a great number of marine species, both animals and plants. Macroinvertebrates $(>0.5 \mathrm{~cm})$ are the most abundant and diverse animal group on rocky shores (Little \& Kitching, 1996).

Organisms found on rocky shores must endure harsh environmental conditions during tidal changes. The intertidal rocky ecosystem gives shelter to numerous species that cannot be found in other places and that play essential roles in ecosystem functioning (Londoño-Cruz, 2007). Physiological limits and biological interactions are factors that influence the vertical distribution of organisms in the intertidal zone (Little \& Kitching, 1996). This vertical distribution has been extensively studied, and the results have shown general spatial distribution patterns for the communities inhabiting the intertidal rocky shores (Benedetti-Cecchi, 2001). Comparisons of distribution patterns between tropical and temperate rocky shores have shown differences mainly due to seasonality (Cole, Creese, Grace, Irving \& Jackson, 1992).
Scientific studies on tropical rocky shores are scarce compared with those conducted on temperate rocky shores (Jimenez, Márquez \& Díaz, 2004). Even scarcer are the studies that have been carried out on Colombian shores, since there has been more interest in research on other ecosystems (e.g. coral reefs, mangroves). Although $636 \mathrm{~km}$ of Colombian Pacific coast are rocky shores (Londoño-Cruz, Cuellar \& Castellanos-Galindo, 2008), only a small percentage of it has been studied. Rocky shores on Gorgona Island and Bahía Málaga have been the best investigated areas on the Colombian Pacific; however, most of these studies are taxonomic inventories (e.g. Barrios \& López-Victoria, 2001; Invemar, Univalle \& Inciva, 2006), and information on the distribution of species along the different intertidal zones is very scant. The objective of the present study was to identify macroinvertebrate species on rocky shores of Gorgona Island and to determine and compare the richness, abundance, diversity (Shannon index), and evenness (Pielou index) among various localities and between intertidal zones at La Ventana.

\section{MATERIALS AND METHODS}

Study site: Gorgona is an island of volcanic origin on the Colombian Pacific coast (2 $2^{\circ} 8^{\prime} 03$ ” $\mathrm{N}-78^{\circ} 10^{\prime} 49^{\prime \prime} \mathrm{W}$ ), about $30 \mathrm{~km}$ from the nearest point on the continent, Punta Bazán, Cauca. It is the largest island on the Colombian Pacific (c.a. $13.3 \mathrm{~km}^{2}$ ), characterized by high rainfall, ranging between 4164 and $8176 \mathrm{~mm}$ annually. The average humidity exceeds $90 \%$, and the monthly average temperature of surface water ranges between 26 and $28^{\circ} \mathrm{C}$ (Barrios \& López-Victoria 2001). Different marine ecosystems are found on the island: coral reefs, sandy beaches, and rocky shores. As a result of its volcanic origin, rocky shores are the most extensive marine ecosystem on the Island.

Four localities were sampled around the Island: La Ventana (Ven) (2०56'19' $\left.\mathrm{N}-78^{\circ} 12^{\prime} 20^{\prime \prime} \mathrm{W}\right)$, La Camaronera (Cam) (2॰57'24” N - 78॰12'54” W), La Mancora (Man) (2॰56’00” N - 78 $\left.12^{\circ} 07^{\prime} ” \mathrm{~W}\right)$, and El 
Muelle (Mue) $\left(2^{\circ} 57^{\prime} 33^{\prime \prime} \mathrm{N}-78^{\circ} 08^{\prime} 41^{\prime \prime} \mathrm{W}\right)$. Ven is a rocky platform with a gentle slope located at the southern end of the Island, in front of the islet of Gorgonilla. Besides the rocky platform, large blocks and boulders are found towards the direction of El Cocal (Playa Palmeras), a large sandy beach; towards the opposite direction (Punta Brava), many tidal pools are found. Mue, located at the west margin of Gorgona Island, has narrow mid and high zones, composed mainly of cobbles and pebbles as well as gravel and sand; the lower zone is made of cobbles, boulders and small blocks. These two localities are located on the eastern coast of the Island facing the continent. Cam and Man are located on the western coast of the Island (facing the open sea) and have high and middle intertidal zones composed mainly of sand and gravel; boulders, blocks, bare rock and tide pools are found only on the lower intertidal zone of these localities.

Sampling procedures: Sampling was carried out twice. Ven and Cam were sampled in October 2010 while Mue and Man were sampled in March 2011. Two methodologies were used: rapid ecological assessments for qualitative data and quadrats for quantitative data. Both, rocks and crevices were meticulously searched for macroinvertebrates. Rocks that were moved were left as initially found in order to reduce the disturbance of the sampling (Chapman and Underwood, 1996). Most of the identification was done in situ; only individuals of uncertain identification were collected for its posterior identification in the laboratory. Identification of species was based on Keen (1971), Fauchald (1977), Brusca (1980), Hickman (1998), Hickman and Finet (1999), Hickman and Zimmerman (2000), and Cantera, López de Mesa, Ocampo \& Cuellar (2011). All collected material was deposited in the Marine Biology Reference Collection of the Universidad del Valle (CRBMUV).

Due to the characteristics (i.e. composition of the shore substrate) of the four localities,
Mue, Cam, and Man were only sampled in the low intertidal zone; while Ven was sampled in the high, middle and low intertidal zones since it had rocky substrate all along the intertidal. Additionally, Ven, due to its complexity, was subdivided into four different locations: Ven1: consisting of small rocks (gravel), Ven2: boulders and blocks, Ven3: rocky platform and boulders, and Ven4: rocky platform and intertidal pools.

Rapid ecological assessments: The research team (five people) distributed around each locality/zone and searched actively for benthic macroinvertebrates covering as much area as possible during the spring tide. Intertidal zones (low, middle, high) were defined through conventional methods and tidal charts. At each locality/zone, several quadrats $(0.25 \times 0.25 \mathrm{~m})$ were randomly placed; the number of quadrats was proportional to the area of the locality: 72 for Ven (including the 3 zones), 18 for Cam, 6 for Man, and 6 for Mue. All macroinvertebrates inside the quadrats were identified and counted. With this information, richness, abundance, diversity (Shannon-Wiener H'), and evenness (Pielou J') were calculated for each locality and for each intertidal zone/division in Ven using PRIMER 6.

All data were tested for normality (Shapiro-Wilk test) and homogeneity of variances (Levene's test). When the assumptions were not met, variables were transformed. Richness, diversity and evenness were transformed using Box-Cox, while abundance was transformed using natural logarithm. After transformation, richness did not meet normality and only evenness did not meet any of the parametric assumptions, hence no statistical analysis was performed on this variable. Richness and abundance were tested for differences between localities/zones using a one way ANOVA, while diversity was analyzed with a KruskalWallis test. The Tukey test was used for the post-hoc analysis. All statistical analyses were carried out with Statistica 6. 


\section{RESULTS}

Macroinvertebrates were abundant and conspicuous on rocky intertidal shores of Gorgona Island. One hundred twenty-one species of species macroinvertebrates were found during the sampling period. In all localities, Mollusca was the richest and most abundant taxon (46\% of the species and $59 \%$ of the individuals), followed by Crustacea (32\% of the species and $33 \%$ of the individuals) (Fig. 1). The other groups accounted for the remaining $22 \%$ of the richness and less than $10 \%$ of the abundance.

\section{Distribution of macroinvertebrates} along an intertidal gradient (La Ventana): Macroinvertebrate proportions found in the different intertidal zones in Ven were equivalent to the general results, with a clear dominance of mollusks and crustaceans (Fig. 2). In the high zone, the only macroinvertebrate species

\section{A}

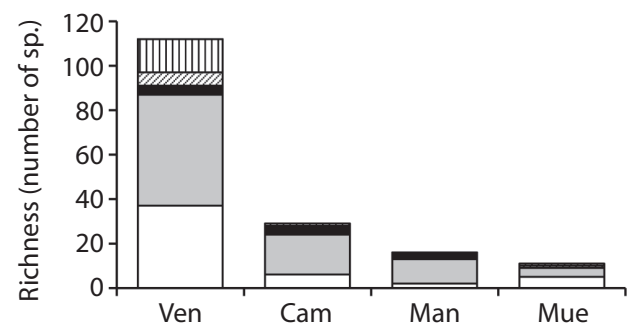

B

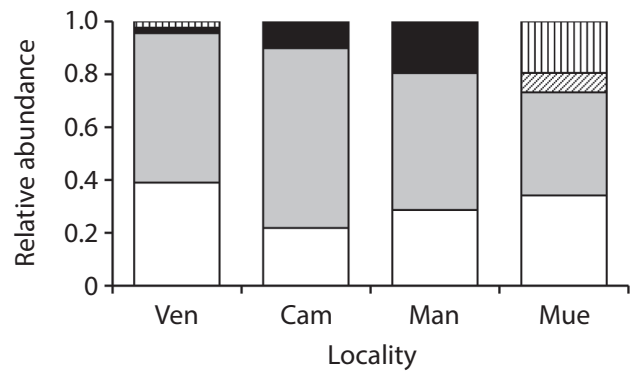

Fig. 1. (A) Species richness, and (B) relative abundance of the different taxa of macroinvertebrates (Mollusca: white, Crustacea: grey, Echinodermata: black, Polychaeta: diagonal lines, and other: vertical lines) found in the different localities (Ven: La Ventana, Cam: La Camaronera, Man: La Mancora, and Mue: El Muelle). The group others includes Sipuncula, Platyhelminthes and Brachiopoda. found were from these two taxa. Dominant species were found in all zones. In the high zone, Nerita scabricosta Lamarck, 1822 and Echinolittorina aspera (Philippi, 1846) were the most abundant. Clibanarius albidigitus Nobili, 1901 and Nerita funiculata Menke, 1851 were abundant both in the low and middle zones. Calcinus obscurus Stimpson, 1859 was also abundant in the low zone and Radsiella dispar (Sowerby, 1832) in the middle. All three zones presented exclusive species: 47 in the low zone [e.g. Turbo saxosus W. Wood, 1828, Stenoplax limaciformis (Sowerby in Broderip and Sowerby 1832), Eryphia squamata (Stimpson, 1860)], 32 in the middle zone [e.g. Petrolisthes edwarsii (D Saussure, 1853), Holothuria portovallartensis Caso, 1954, Tegula pellisserpentis (Wood, 1828)], and 4 in the high zone [e.g. E. aspera, Echinolittorina modesta (Philippi 1846)]. The different response variables showed a decreasing pattern from the low to the high intertidal (Fig. 3). A clear difference was observed between the high and the low and middle zones, with the high zone showing

A

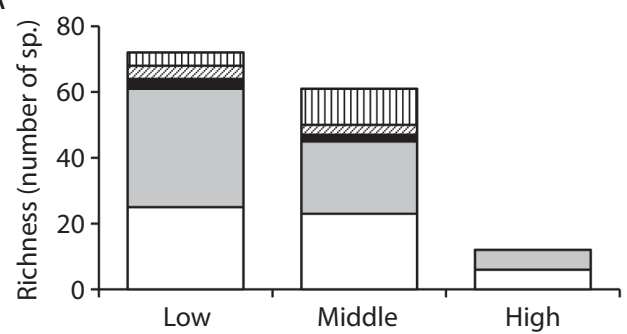

B

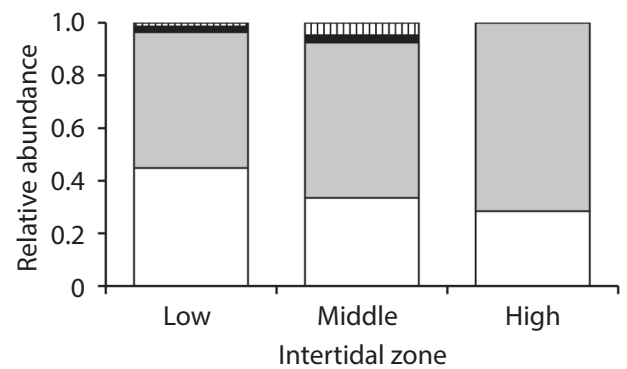

Fig. 2. (A) Species richness, and (B) relative abundance of the different taxa of macroinvertebrates found in the low, middle, and high intertidal zones of La Ventana. Captions as in Fig. 1. 
A

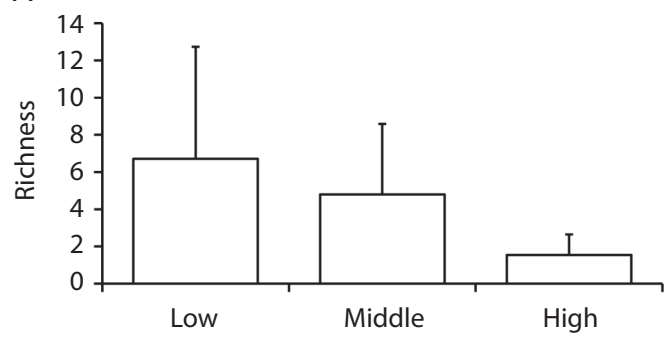

C

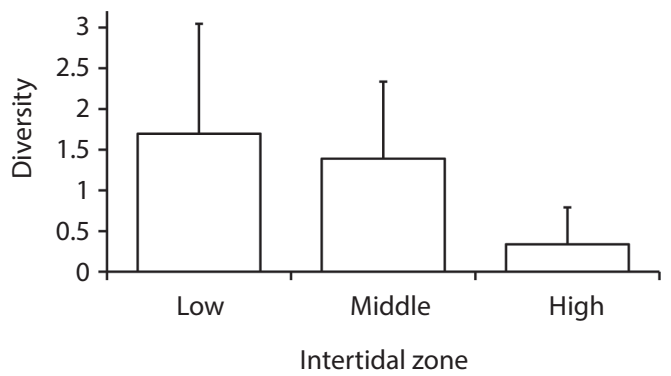

B

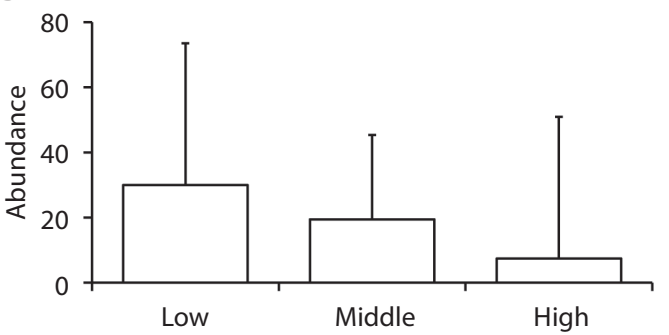

D

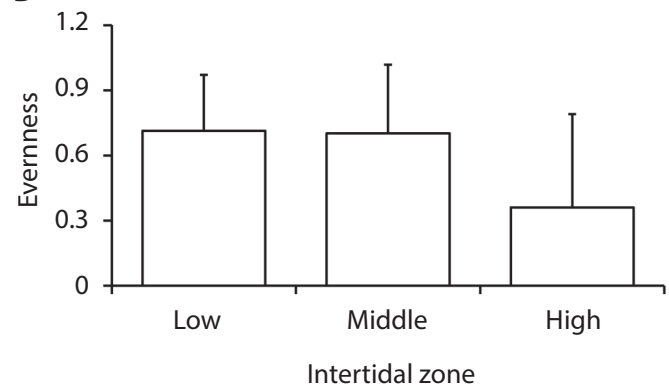

Fig. 3. Average ( \pm SD) Richness (A), Abundance (B), Diversity (H') (C), and Evenness (D) of macroinvertebrates along the different intertidal zones of La Ventana.

the lowest values. The clear dominance of $E$. aspera and E. modesta was reflected in its low equitability (Fig. 3 D).

The one-way ANOVA showed significant differences between zones for abundance $(p=0.002, F=6.8, D F=2)$ and richness $(p<0.001$, $F=14.8, D F=2)$. According to the Tukey test, the abundance was lower in the high intertidal as compared to the middle $(p=0.027)$ and the low $(p=0.002)$ intertidal zones. The richness showed the same pattern, with the high intertidal being significantly less rich than the middle and low zones $(p<0.001$ for both). No statistical differences were found between middle and low zones for either abundance or richness, but there was a tendency for the low zone to show higher values. The Kruskal-Wallis test results for the diversity index were equivalent to the ANOVA results $(p<0.001)$, showing differences between the high zone and the other two zones (Tukey test $p<0.001$ ).

Comparisons between low intertidal zones of different localities in Gorgona
Island: The dominance of mollusks and crustaceans found in Ven was also found at the other localities. A total of 1731 macroinvertebrates were recorded in the low intertidal zones sampled in Gorgona Island, represented by 111 species. Mollusks and crustaceans were the richest (36-69\% and $13-50 \%$ respectively) and most abundant (mollusks $11-68 \%$ and crustacean 22-89\%) taxa (Fig. 4A and 4B). Calcinus obscurus, C. albidigitus, $R$. dispar, and $N$. funiculata stand out for their high abundances in various localities. The dominant species at each locality/division were: C. obscurus (68\%) in Ven1, C. albidigitus (50\%) and $R$. dispar (24\%) in Ven2, Tegula panamensis Philippi, $1849(15 \%)$ and $R$. dispar (10\%) in Ven3, $N$. funiculata (35\%) and C. obscurus (26\%) in Ven4, N. funiculata (49\%) and C. obscurus $(15 \%)$ in Cam, T. panamensis $(25 \%)$ and $C$. obscurus $(21 \%)$ in Man, and $N$. funiculata $(22 \%)$ in Mue.

Ven4 showed by far the highest values for all response variables except for evenness, while Ven1 had the lowest values for most of 


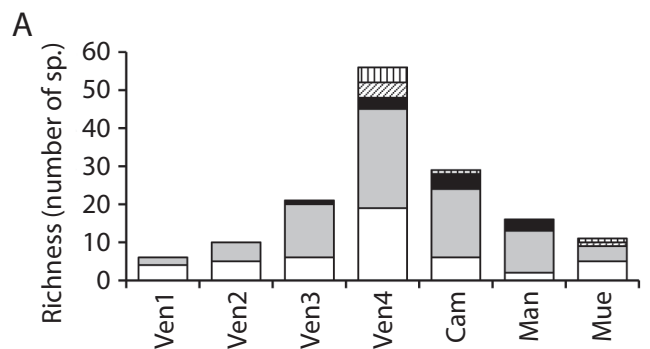

B

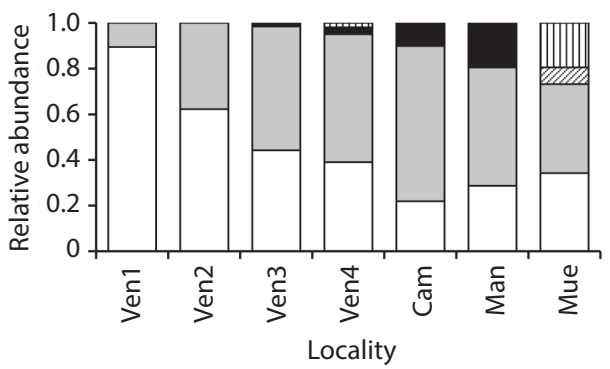

Fig. 4. (A) Species richness per taxa, and (B) relative abundance per taxa of the macroinvertebrates recorded in the low intertidal zone. the variables except for abundance (Fig. 5). In evenness, differences between localities were less than the differences observed in the other variables. The ANOVA results gshowed that there were significant differences between localities for all response variables except for evenness (richness $p<0.0001, F=8.23, G L=6$; abundance $p<0.0001, F=5.20, G L=6$; diversity $p<0.0001, F=6.10, G L=6$; and evenness $p=0.43, F=1.01, G L=6$ ). For species richness, the differences were between Ven1 and Man $(p=0.012)$ and between Ven 4 and all localities except with Man ( $p=0.181$ ) (Fig. 5A). The differences in abundance were found between Ven4 and Ven $1 \quad(p<0.001)$, Ven2 $(p=0.015)$, Cam $(p=0.011)$, and Mue $(p=0.001)$ (Fig. 5 B). As for diversity, the significant differences were found again between Ven 4 and Ven1 $(p<0.001)$, Ven2 $(p=0.003)$, Cam $(p=0.002)$, and Mue $(p<0.001)$ (Fig.5C). All these are evidences that highlight the importance of Ven4 low intertidal zone as compared to all other localities sampled in the Island.
A

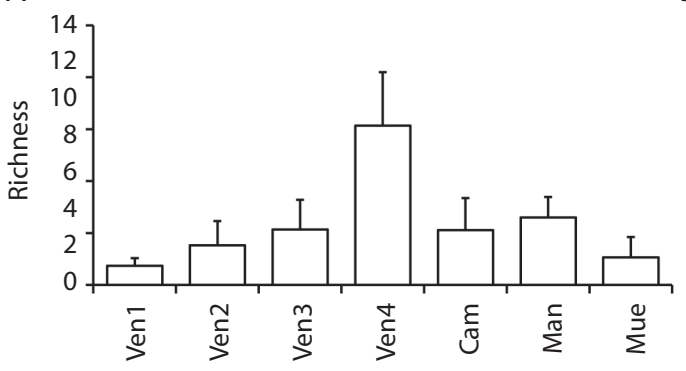

C

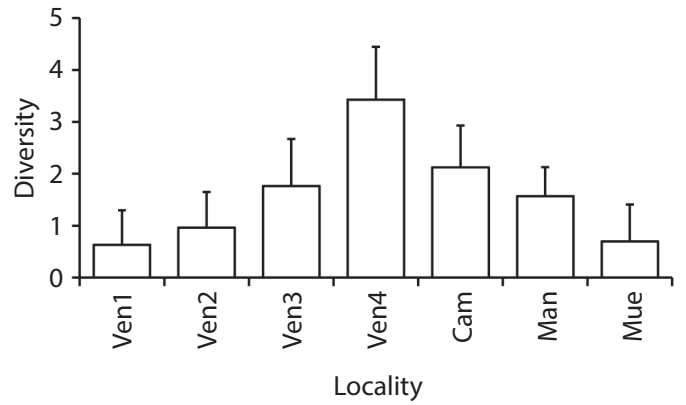

B

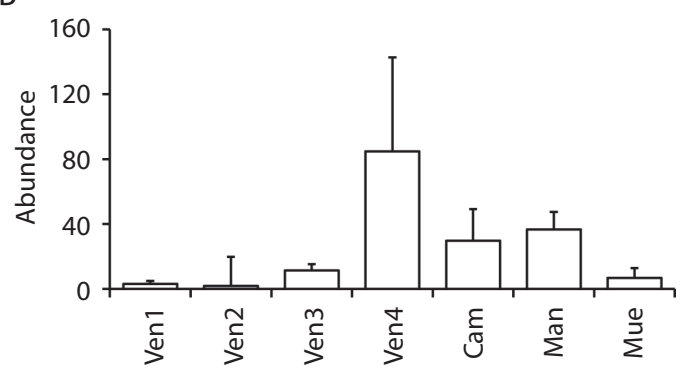

D

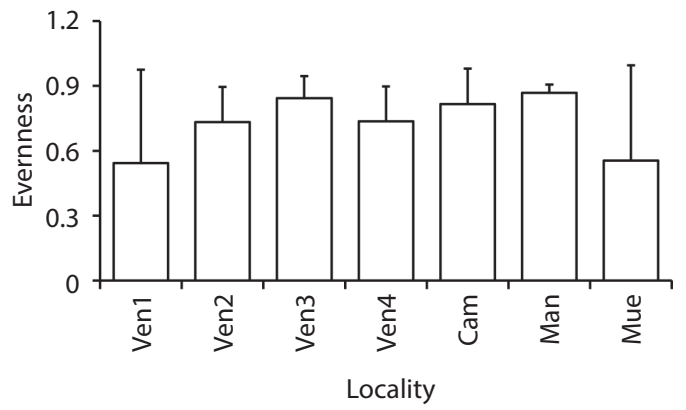

Fig. 5. Average ( \pm SD) (A) Richness, (B) Abundance, (C) Diversity (H'), and (D) Evenness of macroinvertebrates sampled in the low zones of different localities in Gorgona Island. 


\section{DISCUSSION}

Several studies have demonstrated that mollusks and crustaceans are the richest and most abundant taxa in marine benthic communities (Archambault \& Bourget, 1996; De Almeida \& Coelho, 2008); this has also been the case for Gorgona Island and other places along the Pacific coast of Colombia, such as Bahía Málaga, Golfo de Cupica and Cabo Marzo (Invemar et al., 2006; Londoño-Cruz \& Cuellar, 2008; Londoño-Cruz et al., 2008).

Within mollusks and crustaceans, the most representative group in tropical rocky shores is the herbivore gastropods (Paredes, Cardoso \& Tarazona, 1999; Invemar et al., 2006; SibajaCordero \& Vargas-Zamora, 2006). Herbivory, a determinant factor in species spatial distribution on tropical rocky shores (Cruz-Motta, 2007) was a common feature among the most abundant species found in Gorgona's intertidal rocky ecosystems. Another important structuring force in the rocky intertidal ecosystem is the stressful conditions imposed by physical factors, such as desiccation, and the relative importance of these factors to different species may be reflected by characteristic adaptations of the species inhabiting these areas. The differential zonation of the species along the vertical gradient in the intertidal zone is imposed by physical stress on one hand and interspecific interaction on the other (Little \& Kitching, 1996).

Vertical zonation is a worldwide feature of rocky intertidal shores (Benedetti-Cecchi, 2001). The distribution, abundance, and diversity of intertidal assemblages through the different zones depend on factors such as desiccation, thermal fluctuations, and high irradiation (Sibaja-Cordero \& Vargas-Zamora, 2006; Bertocci, Maggi, Vaselli \& BenedettiCecchi, 2010). In the high zone of Ven, which is the zone with the most extreme conditions, all response variables were significantly lower in comparison to the middle and low zones. This pattern of lower richness, diversity, and abundance on the high zone has been found on tropical and temperate rocky shores
(Londoño-Cruz \& Cuellar, 2008; Scrosati \& Heaven, 2007). As expected, and according to what was previously mentioned, the species composition also varied between zones in Ven. Since most species that inhabit the intertidal zone have reduced distribution, the different zones might be characterized by certain species (Little \& Kitching, 1996).

In Gorgona Island, N. scabricosta and E. aspera were characteristic of the high intertidal zone. These species have also been identified as characteristic of this zone elsewhere (Garrity, 1984, Sibaja-Cordero \& Vargas-Zamora, 2006) and have been previously reported in Gorgona's rocky ecosystems (Cantera et al., 1979). The morphological and behavioral adaptations of these species make them resistant to the harsh conditions of the high intertidal. For example, neritids and littorinids form multilayer aggregations, lose extravisceral water at a controlled rate, and reduce tissue temperature by evaporative cooling (Garrity, 1984).

In the middle and low intertidal zones of Ven, the dominant species were the same as those found in other studies. For example, the snail $N$. funiculata was a very abundant species in both zones of Ven. This intertidal distribution for $N$. funiculata seems to be the common pattern in the region (Garrity, 1984). On the other hand, C. obscurus, a typical and abundant species on the low zone of rocky intertidal ecosystems (Bertness, 1981), showed the same pattern in Ven (i.e. very abundant at the low intertidal zone). Another hermit crab (C. albidigitus) was very abundant, both in the middle and low intertidal zones; this species has been reported in high abundances in the middle (Bertness, 1981) and high (Sibaja-Cordero \& Vargas-Zamora, 2006) zones in Panamá and Costa Rica respectively.

This result is very interesting and may suggest that some biological interaction or some other factors (physical or chemical) might be affecting the vertical distribution of this species in Gorgona; more studies should be done to clarify this shift in zonation. Overall, it is important to study the factors controlling the distribution of the different trophic 
groups on Gorgona Island's rocky intertidal ecosystems, because they determine the community structure.

Results of the comparisons between different localities on Gorgona Island also showed the effects of the environmental stress of intertidal zones on the species distribution. The richness, abundance, and diversity in Ven4 were significantly higher than the other sites in the majority of the pairwise comparisons. These high values are probably a result of the high heterogeneity and the presence of relatively large tide pools at this site. Cam and Man, the other two localities where tide pools were found, also exhibited high values, and the differences between Ven 4 and these two places were not as significant as with the other sites. Hence, we believe that tide pools are a key microhabitat that increases the number of species that can inhabit an intertidal site. Several authors (Menge \& Sutherland, 1987; Metaxas \& Scheibling, 1994; Archambault \& Bourget, 1996; Londoño-Cruz et al., 2008) have stated that tide pools offer microhabitats with less fluctuating conditions than the rest of the intertidal zone for organisms, hence providing refuge from extreme conditions when the intertidal zone is exposed. These relatively constant environmental conditions increase the richness and abundance values in the areas where tide pools are present. Some studies in tropical (Brazil) and temperate (Scotland) zones have shown that the presence of zooplankton in tide pools is also related to these conditions (Metaxas \& Scheibling, 1994; De Andrade, Monteiro-Neto \& Carvalho, 2007). It would be interesting to study in the future, the organisms inhabiting the water in tide pools on Gorgona Island.

Topographic and substrate heterogeneity, not only in tide pools but also in the whole intertidal zone, have been regarded as a crucial factor affecting species distribution, richness, abundance, and diversity of intertidal communities (Archambault \& Bourget, 1996; Londoño-Cruz, 2007; Londoño-Cruz \& Tokeshi, 2007), since a heterogeneous zone contains more microhabitats (Benedetti-Cechi,
2001) that might support a larger number of species. In Gorgona Island, the most heterogeneous locality showed the highest values in all response variables. In Ven4, besides the rocky substrate, sand and algae were also present. In contrast, the least heterogeneous localities (e.g., Ven1 and Mue) showed the least richness, abundance and diversity values (Fig. 3). Low richness values have also been related to substrate instability (McQuaid \& Branch, 1984). Ven1 was the most unstable of all localities, since it was dominated by small rocks and pebbles, which are easier to disturb by swash and overwash. This study provides preliminary evidence suggesting that environmental stress (high temperature and desiccation), habitat heterogeneity and stability are important factors that affect the spatial distribution of macroinvertebrate species on intertidal rocky shores of Gorgona Island.

\section{ACKNOWLEDGMENTS}

The authors express their gratitude to Conservation International, Fondo para la Acción Ambiental y la Niñez, Universidad del Valle and Fundación Squalus for supporting this research. We are also indebted to UAESPNN for granting the implementation (permit number PIBD-DTSO-011-10) of this research, especially Maria Ximena Zorrila and the staff at PNN Gorgona; all their support and commitment to research in their park is highly appreciated. The recommendations of three anonymous reviewers highly improved the original manuscript. This paper is a product of the project: "Assessment of the current status of wildlife conservation targets of Gorgona Island: a holistic approach to ecological assessment of Gorgona National Natural Park.

\section{RESUMEN}

Se estudió la distribución especial de los macroinvertebrados asociados al intermareal rocoso de la Isla Gorgona, Colombia (Pacífico Oriental Tropical). Los muestreos se hicieron en cuatro localidades alrededor de la Isla: La Ventana y La Camaronera (muestreadas durante Octubre 
de 2010) y La Mancora y El Muelle (muestreadas durante Marzo de 2011). Se usaron dos métodos: evaluaciones ecológicas rápidas para datos cualitativos y cuadrantes para datos cuantitativos. Se calcularon la riqueza, la abundancia, la diversidad de Shannon-Wiener (H'), y la equidad de Pielou (J') de las muestras y se compararon, usando ANOVA de una vía, entre las diferentes localidades y las tres zonas intermareales de La Ventana (ver métodos). Se encontraron 121 especies de macroinvertebrados durante el estudio. En todas las localidades, Mollusca fue el taxón más rico y abundante (46\% de las especies y 59\% de los individuos), seguido por Crustacea (32\% de las especies y $33 \%$ de los individuos). Los otros grupos equivalieron al $22 \%$ de la riqueza y menos $8 \%$ de la abundancia. Muchos estudios han mostrado que los moluscos y los crustáceos son los taxa más ricos y abundantes en las comunidades bentónicas marinas. La mayoría de las especies más abundantes fueron herbívoros. La composición específica varió entre zonas. Los resultados de las especies dominantes para cada zona son consistentes con los observados en otras costas rocosas intermareales tropicales. Todas las variables de respuesta mostraron un patrón decreciente desde la zona intermareal baja a la alta (en La Ventana). Los resultados post-hoc indicaron que la zona superior, la zona con las condiciones ambientales más rigurosas, tuvo valores significativamente más bajos que las otras dos zonas para todas las variables de respuesta. Las comparaciones entre las zonas intermareales bajas de las diferentes localidades en la Isla Gorgona mostraron valores más altos en todas las variables de respuesta para las localidades con charcos intermareales. Las localidades más homogéneas topográficamente mostraron la riqueza, abundancia y diversidad más bajas. Se conoce que tanto los charcos intermareales como la heterogeneidad y/o microtopografía del sustrato ofrecen refugio a los organismos habitantes del intermareal contra condiciones físicas extremas. Los resultados sugieren que el estrés ambiental, la heterogeneidad y la estabilidad son factores importantes que afectan la distribución espacial de las especies de macroinvertebrados de las costas rocosas intermareales de la Isla Gorgona.

Palabras clave: macroinvertebrados marinos, ecosistema intermareal rocoso, Pacífico Oriental Tropical, distribución espacial, Colombia.

\section{REFERENCES}

Archambault, P. \& Bourget, E. (1996). Scales of coastal heterogeneity and benthic intertidal species richness, diversity and abundance. Marine Ecology Progress Series, 136: 111-121.

Barrios, L. M. \& Lopez-Victoria, M. (2001). (Eds.). Gorgona Marina: contribución al conocimiento de una isla única. INVEMAR, Serie Publicaciones Especiales No. 7. Santa Marta, Colombia.
Benedetti-Cecchi, L. (2001). Variability in abundance of algae and invertebrates at different spatial scales on rocky sea shores. Marine Ecology Progress Series, 217: 79-92.

Bertness, M. D. (1981). Competitive dynamics of a tropical hermit crab assemblage. Ecology, 62(3): 751-761.

Bertocci, I., Maggi, E., Vaselli, S. \& Benedetti-Cecchi, L. (2010). Resistance of rocky shore assemblages of algae and invertebrates to changes in intensity and temporal variability of aerial exposure. Marine Ecology Progress Series, 400: 75-86.

Brusca, R. C. (1980). Common intertidal invertebrates of the Gulf of California. The University of California Press, USA.

Cantera, J. R., Rubio, E. A., Borrero, F. J., Contreras, R., Zapata, F. \& Buttkus, E. (1979). Taxonomía y distribución de los moluscos litorales de la isla de Gorgona Colombia. In H. Prahl, M. Groghl \& F. Guhl (Eds.), Gorgona (pp. 141-168). Universidad de los Andes, Bogotá, Colombia.

Cantera J. R., López de Mesa, L. A., Ocampo, M. A. \& Cuellar, L. M. (2011). Moluscos. In J. Cantera (Ed.), Estadios de vida vulnerable de organismos marinos de Bahía Málaga (p. 29-70). Guía para su identificación. Programa Editorial Universidad del Valle. Cali, Colombia.

Chapman M. G. \& Underwood, A. J. (1996). Experiments on effects of sampling biota under intertidal and shallow subtidal boulders. Journal of Experimental Marine Biology and Ecology, 207:103-126.

Cole, R. G., Creese, R.G., Grace, R. V., Irving, P. \& Jackson, B. R. (1992). Abundance patterns of subtidal benthic invertebrates and fishes at the Kermadec Islands. Marine Ecology Progress Series, 82: 207-218.

Cruz-Motta, J. J. (2007). Spatial analysis of intertidal tropical assemblages associated with rocky shores in Venezuela. Ciencias Marinas, 32 (2): 133-148.

Davis A. N. \& Wilce, R. T. (1987). Algal diversity in relation to physical disturbance: a mosaic of successional stages in a subtidal cobble habitat. Marine Ecology Progress Series, 37: 229-237.

De Almeida, A. O. \& Coelho, P. A. (2008). Estuarine and marine brachyuran crabs (Crustacea: Decapoda) from Bahia, Brazil: checklist and zoogeographical considerations. Latin American Journal of Aquatic Research, 36: 183-222.

De Andrade, F. E., Monteiro-Neto, C. \& Carvalho, M. (2007). Temporal and spatial variations in tidepool fish assemblages of the northeast coast of Brazil. Biota Neotropica, 7: 111-118.

Fauchald, K. (1977). The polychaete worms. Definitions and keys to the orders, families and genera. Natural 
History Museum of Los Angeles County Science Series 28, Los Ángeles, USA.

Garrity, S. (1984). Some adaptations of gastropods to physical stress on a tropical rocky shore. Ecology, 65: 559-574.

Hickman Jr., C. P. (1998). Guía de campo sobre estrellas de mar y otros equinodermos de Galápagos. Sugar Spring Press, Virginia, USA.

Hickman Jr., C. P. \& Finet, Y. (1999). A field guide to marine molluscs of Galápagos. Sugar Srping Press, Virginia, USA.

Hickman Jr., C. P. \& Zimmerman, T. L. (2000). A field guide to crustaceans of Galápagos. Sugar Spring Press, Virginia, USA.

Invemar, Univalle \& Inciva. (2006). Biomálaga: valoración de la biodiversidad marina y costera de Bahía Málaga (Valle del Cauca, Pacífico colombiano) como uno de los instrumentos necesarios para que sea considerada un área protegida (Informe científico final). Retrieved from http:/www.invemar.org.co/redcostera1/invemar/docs/9860IF_BIOMALAGA2007.pdf

Jimenez, M., Márquez, B. \& Díaz, O. (2004). Moluscos del litoral rocoso en cuatro localidades del estado Sucre, Venezuela. Saber, Universidad del Oriente, Venezuela, 16: 9-18.

Keen, M. (1971). Sea shells of tropical west America, second edition. Stanford University Press, USA.

Little, C. \& Kitching, J. A. (1996). The biology of rocky shores. Oxford University Press, New York, USA.

Londoño-Cruz, E. (2007). Patterns of spatio-temporal dynamics in a mobile molluscan assemblage on a subtropical boulder shore (Doctoral dissertation). Kyushu University, Kyushu, Japan.

Londoño-Cruz, E. \& Tokeshi, M. (2007). Testing scale variance in species-area and abundance-area relationships in a local assemblage: an example from a subtropical boulder shore. Population Ecology, 49: 275- 285

Londoño-Cruz, E. \& Cuellar, J. L. (2008). Fauna asociada a zonas rocosas intermareales en las localidades de Piñas y Cabo Marzo (Chocó), zona norte de la costa pacífica colombiana. In B. Valencia \& A. Giraldo (Eds.), Caracterización ecológica de los arrecifes coralinos y bosques de manglar en Cabo Marzo, zona norte del litoral Pacifico colombiano: estructura, composición, diversidad y fauna asociada. Informe Técnico Final. (pp. 164-179). Convenio de Cooperación Conservación International FoundationUniversidad del Valle. Cali, Colombia.
Londoño-Cruz, E., Cuellar, J. L. \& Castellanos-Galindo, G. A. (2008). Fauna asociada a la zona rocosa intermareal en las localidades de Cambura (Punta Cruces) y El Acuario (Cabo Marzo). In A. Giraldo \& B. Valencia (Eds.), Chocó. Paraíso por Naturaleza: Punta Cruces y Cabo Marzo (pp. 77-89). Universidad del Valle. Cali,Colombia.

McQuaid, C. D. \& Branch, G. M. (1984). Influence of sea temperature, substratum and wave exposure on rocky intertidal communities: an analysis of faunal and floral biomass. Marine Ecology Progress Series, 19: 145-151.

Menge, B. A. \& Sutherland, J. P. (1987). Community regulation: variation in disturbance, competition, and predation in relation to environmental stress and recruitment. American Naturalist, 130: 730- 757.

Metaxas, A. \& Scheibling, R. E. (1994). Spatial and temporal variability of tidepool hyperbenthos on a rocky shore in Nova Scotia, Canada. Marine Ecology Progress Series, 108: 175-184.

Osman R. W. (1977). The establishment and development of a marine epifaunal community. Ecological Monographs, 47: 37-63.

Paredes, C., Cardoso, F. \& Tarazona, J. (1999). Invertebrados del intermareal rocoso del departamento de Lima, Perú: una lista comentada de especies. Revista Peruana de Biología, 6: 143-151.

Scrosati, R. \& Heaven, C. (2007). Spacial trends in community richness, diversity, and evenness across rocky intertidal environmental stress gradients in eastern Canada. Marine Ecology Progress Series, 342:1-14.

Shanks A. L \& Wright, W. G. (1986). Adding teeth to wave action: the destructive effects of waveborne rocks on intertidal organisms. Oecología, 69: 420-428.

Sibaja-Cordero, J. A. \& Vargas- Zamora, J. A. (2006). Zonación vertical de epifauna y algas en litorales rocosos del Golfo Nicoya, Costa Rica. Revista de Biología Tropical, 54: 49-67.

Sousa W. P. (1979a). Experimental investigations of disturbance and ecological succession in a rocky intertidal algal community. Ecological Monographs, 49: 227-254.

Sousa W. P. (1979b). Disturbance in marine intertidal boulder fields: the nonequilibrium maintenance of species diversity. Ecology, 60: 1225-1239.

Sousa W. P. (1984). Intertidal mosaics: patch size, propagule availability, and spatially variable patterns of succession. Ecology, 65: 1918-1935. 